\title{
Pastoral Banking Practice - A Christian-ethical and pastoral perspective on financing, credit and moneylending
}

Authors:
Morten Bøsterud ${ }^{1}$
Jakobus M. Vorster ${ }^{1}$
Affiliations:
'The Unit for Reformational
Theology and the
Development of the South
African Society, Faculty of
Theology, North-West
University, Potchefstroom,
South Africa
Corresponding author:
Morten Bøsterud,
morten@bosterud.no
Dates:
Received: 18 Sept. 2018
Accepted: 31 Jan. 2019
Published: 14 Mar. 2019
mobile device
to read online.
How to cite this article:
Bøsterud, M. \& Vorster, J.M.,
2019, 'Pastoral Banking
Practice - A Christian-ethical
and pastoral perspective on
financing, credit and
moneylending', In die Skriflig
53(1), a2409. https://doi.org/
10.4102/ids.v53i1.2409
Copyright:
C 2019. The Authors.
Licensee: AOSIS. This work
is licensed under the
Creative Commons
Attribution License.

Financing of human activity through borrowing from third parties is widespread in the Western world. Such financing may give rise to several questions of moral and ethical character. The ethical underpinnings of such banking activity are somewhat unclear and not uniform among the involved actors. Christian thinkers have been divided as to what moral norms should apply and, traditionally, the matter has been discussed mostly in connection with the level of interest charged by the lender to the borrower. In this article, banking is illuminated from different angles, including questions regarding the moral defensibility of lending and borrowing, the taking and posting of collateral, third party guarantees and the level of interest that may be charged. A new banking system is proposed, whereby banking is given a constructive and participatory societal place in concert with sound Christian-ethical and pastoral principles. This new banking paradigm is named Pastoral Banking Practice (PBP) to emphasise its Christian-ethical and pastoral foundations.

\section{Introduction}

Within the economic sphere of individuals and societies, activities need be financed, whether they be commercial enterprises or expenditures of a private nature such as, for example, purchasing dwellings or paying for education, or to consume for self-subsistence. Financing human activity can be performed in principally two different ways: by way of utilising equity belonging to the initiator, or by receiving loans, credit or equity from a third party. Superficially, it may be assumed that there is a defined line between credit and equity financing, but these methods may typically co-exist in an equity loan mix. Despite the prevalence of third-party financing, currently in use in Western economies, it is not a given that the extension of credit is without moral implications and that its use may influence individuals and society in ways which are not only beneficial. This article will examine how financing credit, moneylending and charging of interest can be viewed in a Christian-ethical and pastoral perspective as seen on the foundation of the reformed paradigm.

This article illustrates how credit extension and financing are always value-driven, and that banking practices may beneficially be performed according to Christian-ethical and pastoral principles, and yet remain useful in a societal commercial context. To this end, the authors present a banking system where credit may be utilised in concert with Christian-ethical and pastoral principles which is meant as a moral guide for Christians involved in lending and borrowing. This system is termed Pastoral Banking Practice (PBP) and its foundations within reformed theology will be investigated in this article.

\section{Banking in society}

Banking is an activity related to the concepts of money and debt. There have been and still are various theories on the formations and utility of money and debt, and how they interact with each other as concepts. This article will not enter into this debate, but, for the authors, it will here be built on the premise that money is a social technology, void of intrinsic value, and thus only in existence and use as far as it is practical for measuring and settling inter-actor obligations. Further, it will be built on the premise that from the early beginnings of human society, debt has been a factor in human economic interaction with the invention of money as a later addition where money has been used as means to settle the debts (Graeber 2012; Keynes 1915; Martin 2014). According to this mode of cognition, money and debt are seen as intrinsically interwoven. Also, money will always be seen as debt, but not necessarily the other way around (Martin 2014). To illustrate this point and the point that money is not under government control, a simple 
example will be given: Person A performs a job for his neighbour $\mathrm{B}$, for example mows his lawn, and the price is set at $\$ 100$. If the payment is settled through credit extension, then the parties themselves in reality have 'issued' $\$ 100$. The point here is of course that the money in use in this example has not been issued by any government, but exists only as a measure of value between the parties. Maybe later, B does work for $A$ at the value of $\$ 100$ and the debt is settled through set-off. Then, \$200 has been created, but physically has never seen the light of day and no governmental authority has been involved.

Banking and financing have had great importance for societal developments in the Western world. It has been demonstrated how from the early beginnings debt has been a factor in society with the invention of money as a later addition. As posited above, money will always represent a debt, either to be repaid as money or to be settled with a service or physical goods. However, the notion that money always represents debt, actual or latent, does not automatically indicate that all debt is money. For debt to become money, it will have to be expressed in the measurement which is money. All involved parties must then recognise money as a means to settle the debt. Thus, the construct of money allows for lending and borrowing without any interventions of governments or banks. This will have be the original state of moneylending as also is demonstrated from numerous scriptural passages pertaining to lending and borrowing (e.g. Ex 22:25; Dt 15:8-7).

A central task for the banks in an economic society is to alleviate what may be termed the 'maturity gap' (Martin 2014). The maturity gap occurs when there is a mismatch between what and when one party can claim outstanding debt as settled and what and when he himself has to pay out money to another party. If, for example, in the lawn mowing illustration above, the creditor needed to use the money before he could legally claim them from his debtor, he could go to a bank which will take over the claim and pay liquid money to the creditor, or let all or some of it appear in a deposit account. In this situation, the bank would take over the claim and become the new creditor of the debtor. The picture may vary, but this is a typical situation for banks, as the depositors can regularly withdraw their monies at any time, but the deposits will be covered by the banks' assets of which not all will be liquid. However, as it then will appear, the bank has on the one hand short-term creditors, that is, the depositors, and on the other side of the equation, the bank has become a creditor for debt with longer-term payment obligations such as through its own lending to third parties (Casu, Girardone \& Molyneux 2015).

As often happens, if there is a run on the bank where all or many of the depositors want to withdraw their money at the same time, this maturity gap on the side of the bank can have dire consequences indeed if banks do not have sufficient capitalisation and liquid reserves (Galbraith 2009). A key role of the central banks is to alleviate the strains that the maturity gap places on the commercial banks. This is mainly performed through supplying the commercial banks with sufficient liquidity (Neal 2015). Without such a system of banking, the individual societal actors would not be able to utilise the part of their capital which consists of the debts owed by others, but would have to wait for maturity to occur to put this capital to work or consumption.

Over history, banking and financing have attracted interest from authorities, and despite what could be an intuitive starting point, regulations on banking has been the rule rather than the exception. Already in Old Testament times and beyond we know of regulations such as, for example, the Jubilee years as mentioned in Leviticus 25:10 and debt moratoriums in Deuteronomy 15:1. Also, in the law code of Hammurabi, there were several quite detailed regulations on credit and debt and these would indicate a governmental influence that was seen as necessary to uphold societal values in trading activities and otherwise (Horne \& Johns 2007). Consequently, a completely free market within banking has never occurred in the Western world, as the governments and/or church have weighed in to exert power over the markets and to eradicate the worst excesses of the free market. There have been some modern era attempts to perform banking in an ethically acceptable manner in the Western world, but mainly, this has been based on secular movements connected to stakeholder thinking such as Corporate Social Responsibility, for example the microfinancing movement which occupies only a marginal space within the banking realm at best (McManus 2011; Pava 2008; Zeller \& Sharma 2000). Within Islamic thinking, a religiously based comprehensive banking system has been developed with force over the last four decades which is believed to be in strong growth at the time of writing (EY 2016; Jamaldeen 2012; Kettell 2011).

Within the Christian paradigm, there has only been a few scattered attempts to establish a banking system based on Christian moral norms such as, for example, the Paris-based non-profit organisation called The Christian Finance Observatory (CFO 2017) formed a charter aiming at promoting Christian values within the banking sector. There are also other budding examples from academic theory pointing towards the development of a Christian-ethical and pastoral banking practice. For example, Bøsterud and Vorster (2017) outline a set protocol for investment activity which is wholly based on scripturally founded Christian ethics. These protocols are based on Bøsterud's PhD dissertation (2016) that gives a more comprehensive explanation for the Reoriented Investment Protocol (RIP) which is his main creation. The advent of a comprehensive banking system based on Christian-ethical and pastoral values, which might be seen as typically Western, has yet to materialise in any tangible form. If the Western economic constituent wishes to partake in banking activities according to religion-based morality, the only practical alternative will be that of Islamic banking products. 


\section{Biblical pastoral-ethical norms}

Despite the usefulness of the general ethical and pastoral guidance, which has been described above when developing PBP, several scriptural passages has rendered bankingspecific instruction that has contributed accurate guidance as to how to express the PBP. For developing the PBP, the Christian paradigm of reformed theology is in use, drawing on inspiration from seminal reformed influences such as Calvin (2012), the Westminster Confession (2010) as well as from more recent reformers such as Barth (2009), Berkhof (1969 [1950]) and Grudem (2013) to mention some. However, whilst interrogating Scripture in search for Christian-ethical and pastoral norms applicable to banking and financing, a plain scriptural interpretation aligned with the accepted reformed hermeneutical principles may not completely illuminate the broad realm of problems connected to banking and financing. Thus, the hermeneutical norms in use when perusing Scripture will render valuable guidance, but will not be viewed as comprehensive (Vorster 2017b). The application of postmodern deconstructive interpretative techniques and semiotics will be expected to offer particular added guidance when investigating different modes of financing and their attendant characteristics (Derrida 1997; Foucault 2002; Star \& Griesemer 1989).

\section{Moneylending}

In the Western economic systems, the use of capital belonging to others by way of guarantees, borrowing, interest, et cetera, could easily lead to the conclusion that moneylending, with or without charging interest, is an acceptable mainstay in the socio-economic makeup of the Western societies.

\section{Lending or giving - to the needy only?}

The matter of lending is touched upon in the Old Testament, and as we find stipulations pertaining to lending already in the Pentateuchal books, it may be inferred that the matter is of substantial importance in Scripture, as these early biblical books pertain to binding laws given directly by God to his people. For example, from Exodus 22:25 we understand that the Israelites could 'lend money to one of my people among you who is needy', and in Deuteronomy 15:8-7 we learn that God's people should 'not be hard-hearted or tight-fisted' toward the poor and needy. Rather, they should be 'openhanded and freely lend them whatever they need'. The latter quote will lead to the question as to whether lending only is acceptable to those in need or if it is also acceptable to lend to those who do not need, but only want?

On lending to those not in need, we learn from Exodus 22:25 that to 'lend money' may be considered 'a business deal' and then the concept of interest is introduced as acceptable. From the New Testament, we learn in Luke 6:35 how Jesus advised that even when dealing with our 'enemies' we should 'lend to them without expecting to get anything back'. It would appear from these quotes that the lender is not obligated to lend only to those in need, but can also lend to those not in need and even to his own enemies. On this basis, it could concluded that the act of lending also to those not in need could be considered an acceptable act, both ethically as well as in a pastoral perspective.

\section{Borrowing - a moral act?}

Although it has now been demonstrated that to lend money is an acceptable Christian-ethical and pastoral activity, it may be asked whether it matters if the borrower is in need, how this need is brought about, or if it is acceptable to borrow even when not in need.

As has already been demonstrated, Scripture recognises the concept of lending when not in need (e.g. Ex 22:24; Lk 6:35) and, as there are clear warnings in Scripture about accepting loans, it would be reasonable to infer that receiving a loan is not completely unambiguous in a moral perspective. Examples of this may be found in Proverbs 22:7 where we learn that 'the borrower is slave to the lender', and in Habakkuk 2:7, where it is asked, 'Will not your creditors suddenly arise?' and if so, 'then you will become their prey'. These warnings are also represented in the New Testament where, in Romans 13:8, it is in a universal manner stated, 'Let no debt remain outstanding, except the continuing debt to love one another.'

The repayment aspect is central when borrowing is described in Scripture. For example, in Psalm 37:21 we learn that 'the wicked borrow and do not repay', and in Psalm 15:4 we are instructed to be the one 'who keeps an oath even when it hurts'. From this, it may be inferred that, according to scriptural sources, to enter into debt with the intention to repay, can be seen as acceptable from a moral standpoint as an overriding norm. This does not, however, mean that any form of borrowing is acceptable. A prudent question may be asked whether borrowing for highly speculative ventures may represent a form of greed or covetousness (Lk 12:15; Pr 11:6) which, in itself, renders such borrowing and, indeed, such lending is an unsound practice from a Christian-ethical and pastoral perspective (Chewning 1995:286).

\section{Duration and security}

Although the scriptural sources, as referred to above, support the legitimacy of moneylending and borrowing as principally acceptable societal institutions, it is not given that any format of lending and attendant conditions may be deemed acceptable as seen from a Christian-ethical and pastoral perspective. For example, when does lending become so long-term that it, in reality, represents rent or economic serfdom, and when does the transaction become so riskladen that it could represent economic ruin for the borrower if something fails? These questions are relevant to Western countries when it is necessary to borrow as part of housing needs, by way of mortgages, when entering into more frivolous consumer lending, but even more so when considering how Western lenders could send developing countries into lasting economic bondage through lending, 
especially if the borrowing country has poor national governance (Collier 2008; Easterly 2002).

The matter of duration on loans is mentioned in several biblical passages. A natural starting point is Deuteronomy 15:1 where it is stated that 'at the end of every seven years you must cancel debts', and this is followed up later in 31:10 where Moses specifies that this is to be done 'during the Festival of Tabernacles'. The ethos of the strong looking after the weak permeates the biblical pastoral ethos. For example, in Proverbs 29:7, we are told that 'the righteous care about justice for the poor, but the wicked have no such concern', and in Matthew 5:42, we are instructed to 'give to the one who asks you, and do not turn away from the one who wants to borrow from you'.

The cognition that the lender is considered the more powerful in the lender/borrower relationship, and that the pastoral responsibility of consideration is on the lender, is represented also in other biblical passages. For example, when considering what may be taken as security or collateral for loans, we find in Deuteronomy 24:6, 'Do not take a pair of millstones - not even the upper one - as security for a debt, because that would be taking a person's livelihood as security.' The referred passages pertaining to collateral may seem antiquated to a modern reader and, as there could be no doubt that Scripture allows the taking of collateral for debts, the obligation on the lender is to shepherd and care also for the borrower and exert societal stewardship in this regard also in a modern-day interpretation of Scripture on this point (VanDrunen 2015).

When viewing the above scriptural passages on loan duration and collateral, it becomes evident that Scripture remains ambiguous on the construction of loans. The onus is on the lender to care for the interest of the borrower and not to set the latter in a bondage-like economic situation, as that may be considered detrimental for family and societal values. The borrower, then, must be able to pay back the loan in full within a reasonable time. The fact that the cited passages relate to different biblical and societal contexts spanning from Old to New Testament economic realities, but that they still remain aligned in the protection of the borrower, will lend the overriding espoused principles weight and relevance so that they may safely be transferred to our time.

\section{Charging interest}

The Old Testament starting point on charging interest is that interest is considered immoral when charged on loans to fellow countrymen in need (Ex 22:25; Lv 25:35-35; Dt 23:19). This initial position was already modified in Old Testament passages when the loan was connected to business as appears in Exodus 22:25 where it is antithetically stated that when a loan is not 'a business deal' one should 'charge no interest'. In other words, when entering into business-oriented loans, the charging of interest, in itself, is not to be considered immoral usury. This point is further underscored in Deuteronomy 23:20 where it is clearly stated that 'you may charge a foreigner interest', which would indicate a typical business situation when personal and family aspects are removed from the transaction and the loan becomes part of making added profit, and not for alleviating the plight of the borrower.

Although the Old Testament passages reveal insights directly pertaining to the morality and pastoral aspects of interest on loans, the New Testament is less expressly informative on the matter. However, we do learn from several passages that money and lending was not pastorally or ethically neutral, but, as the New Testament was written in the Roman era, society had become increasingly complex, and the Roman affinity for business and commerce was apparent.

Central New Testament passages, specifically pertaining to banking, are to be found in the two parallel parables of Matthew 25:14-30 and Luke 19:11-27. In these parables we learn of a wealthy man who, when setting out on a journey, entrusted his three servants with amounts of money (indicated as different amounts in Matthew) which they were to take care of while the master was away. Upon the return of the master, the servants had managed their entrusted funds differently. In both stories, two of the servants had invested it and made a profit, while the third had not invested the money, but had kept it as it was given, and subsequently returned to the traveling master the exact amount he had been given. In both parables the two investing servants are praised by their master, and the third non-investor is chastised for being passive with the funds. In both versions of the parable, the master states similarly to the derided servant that 'you should have put my money on deposit with the bankers, so that when I returned I would have received it back with interest' (Mt 25:27).

Because Calvin has been considered to be foundational for developing Protestant views on work, thrift and capitalism (e.g. by Max Weber, 1864-1920), it would be of interest to look a little closer here on how Calvin expressed his views on the charging of interest (Weber 2012).

In his Harmony of the Law, when discussing the morality of interest, Calvin (2017a) refers to the scriptural equity principle as expressed in Matthew 7:12, 'So in everything, do to others what you would have them do to you'. He (Calvin 2017a) then goes on to outline:

Whosoever has any ready money, and is about to lend it, he will allege that it would be profitable to himself if he were to purchase something with it, and that at every moment opportunities of gain are presenting themselves. Thus there will be always ground for his seeking compensation, since no creditor could ever lend money without loss to himself. (p. 159)

The above quote clearly refers to the practice among business people, and even so, Calvin (2017a) urges the terms to be equitable:

Hence it follows that usury is not now unlawful, except in so far as it contravenes equity and brotherly union. Let each one, then, 
place himself before God's judgment-seat, and not do to his neighbour what he would not have done to himself, from whence a sure and infallible decision may be come to. (p. 161)

In a letter to one of his friends, De Usuris Responsum, Calvin (1845) summarises his position on usury, and defends his position in the following terms:

It could be wished that all usury and the name itself were first banished from the earth. But as this cannot be accomplished it should be seen what can be done for the public good ... Therefore usury is not wholly forbidden among us unless it be repugnant both to Justice and to Charity. (n.p.)

Calvin's scriptural interpretations on usury and interest have stood the test of time in reformed theological circles. The position under this paradigm is that, in principle, charging interest is considered wholly acceptable and moral in any loan agreement (Cramp 1995:332).

\section{Risk and stability}

When exploring the moral qualities of banking, the adjacent fields of risk and societal and individual economic stability are central, as from history, we know of numerous examples of banking failures that have led to widespread societal, social and individual disruptions of economic stability and safety.

That material wealth is a good to be enjoyed by humans, is represented in Scripture in several passages, for example in Deuteronomy 8:18 where we learn that material goods are a gift from God, 'for it is he who gives you the ability to produce wealth, and so confirms his covenant'. Clearly then, to receive and enjoy the gift of wealth from God is part of our covenantal duties and, as humans, we are instructed to maintain this gift with gratitude. The Old Testament also warns of the consequences of falling into poverty, as Proverbs 22:7 reveals how 'the rich rule over the poor, and the borrower is slave to the lender'. This latter descriptive quote is probably as true now as when it was written and, suffice to say, the obligation to maintain God's gifts of wealth and not willingly fall into poverty, is still an instruction to be heeded. To banking practice, this instruction will inform how not to practise in a manner where the gift of God may be jeopardised without reason.

The matter of material stability is also represented in New Testament passages. From the Good Shepherd metaphor in John 10:10, we learn how stability and safety is emphasised by Jesus: 'The thief comes only to steal and kill and destroy; I have come that they may have life, and have it to the full.' That societal and material stability is a quality we receive from God, is further represented in James 4:2 where we learn that 'You do not have because you do not ask God'.

Even though wealth is a gift from God, we cannot sit idly by and wait for his gifts to be handed to us without effort. In 2 Thessalonians 3:10 it appears that the one who is unwilling to work shall not eat', and in Proverbs 14:23, 'All hard work brings a profit, but mere talk leads only to poverty.' No doubt this indicates our own obligation to participate in maintaining ourselves materially and that our effort will mirror our outcomes. This leads on to the questions of what risks we are supposed to be willing to take, and whether increased risk lead to increased material outcome. These questions are answered directly in 2 Corinthians 9:6 where we learn that 'whoever sows sparingly will also reap sparingly, and whoever sows generously will also reap generously'. This quote is taken from the context of church planting in the early Christian era and points to how Christians should support each other in the church societies and, given the context of developing a society of the just, the principles contained would have great value when assessing whether risk is allowed when moving societal economic life in general forwards. Clearly then, we are encouraged to take risks in our pursuit of material needs satisfaction. The more risk we take on, the more likely will the outcome proportionately increase.

The above quotes should suffice to develop the scriptural positions on work ethic, material stability and risk-taking, but the parallel parables as referred to above, found in Matthew 25:14-30 and Luke 19:11-27, illustrate the biblical pastoral ethics on this point by using allegorical imagery directly connected to banking which would be fully understandable for today's readers. In these parables, we learn that not only is the idle servant chastised for his idleness and risk-aversity, but the risk-taking servants are rewarded for their initiative, personal effort and level of risk-taking. This becomes particularly clear in Luke where the servants' rewards are in direct proportion to what their investments yielded (Lk 19:16-19). The overall position of the two parables on personal effort and initiative is summarised in Matthew 25:29, 'For whoever has will be given more, and they will have an abundance. Whoever does not have, even what they have will be taken from them.'

To accept and thrive in the free market has become fully acceptable, and should be considered the main position under the reformed paradigm (VanDrunen 2015). This said, to allow risk and uncertainty on all levels may not be according to accepted reformed pastoral ethos, as there will have to be limitations to the level of risk in use for both the individual and the larger society.

To illustrate the other side of risk-taking is to consider whether risk-taking may be so substantial and uncontrolled that it, in reality, equals gambling. Gambling may not be specifically forbidden in Scripture, but the essence of it is considered in some locations. An example would be 1 Timothy 6:10 where it is explained, 'For the love of money is a root of all kinds of evil. Some people, eager for money, have wandered from the faith and pierced themselves with many griefs.' Chasing fast earnings is covered in Proverbs 13:11, 'Dishonest money dwindles away, but whoever 
gathers money little by little makes it grow.' These quotes clearly show that seeking to earn money through excessive risk-taking, for example gambling, is not condoned in Scripture. The ethic that what we earn should be deserved through work is evidenced already in Genesis 3:19, 'By the sweat of your brow you will eat your food', a principle which is replicated in 2 Thessalonians 3:10, 'The one who is unwilling to work shall not eat.'

On the basis of the above referred biblical quotes, it can be concluded that utilising risk in banking and financing is acceptable, but that there are Christian-ethical and pastoral obligations to care for society, and to safeguard others from destabilising the economy as a result of entertaining such financial risk.

\section{Truthfulness}

When practising commercial activities such as banking and financing, the matter of safeguarding prudent levels of information among all involved parties is of importance. Only when all parties are aware of the same risks related to a transaction, they will be able to ascertain whether the risk is sensible to take on. Therefore, it will be important to investigate what Scripture reveals on truthfulness and how influential theological thinkers within the reformed paradigm have interpreted this. An obvious place to start is the Decalogue and, in particular, the 9th commandment (Ex 20:16) where teaching on truthfulness is set out. The commandment in itself, as it is written superficially, pertains directly to the obligation that we 'shall not give false testimony' in a court of law situation. Although the commandment seems to be directed to a specific life situation, there has been no doubt that, when interpreting the passage, the obligation goes beyond the courtroom and obliges us to be truthful in all parts of our lives. The 9th commandment will typically be considered the main scriptural instruction related to thruthfulness: we are not to lie, but to stay truthful in all situations, to everyone and in every situation, and to remain in this state regardless of whomever we interact with (Douma 1996).

Our Christian-ethical and pastoral obligation to stay truthful in our interaction with others is elaborated and illustrated further throughout the Bible and, for example in Leviticus 19:11, it is expressly stated, 'Do not deceive one another.' The specific instructions pertaining to deceit will be of direct influence on the topics in this article, as they point to interaction with others in a manner where one party understands that the other does not have the full picture clear when entering into a transaction and/or when one party is leading another into a state of not realising the full truth. That truthfulness is rewarded in Scripture and it follows directly from Proverbs 12:19, for example where it is stated clearly that 'truthful lips endure forever'.

Calvin's works will shed further light on the reformed position on truthfulness and deceit. In his Institutes, Calvin
(2012), with regards to the 8th commandment (Ex 20:15), writes:

But not to dwell too long in enumerating the different classes, we know that all the arts by which we obtain possession of the goods and money of our neighbours, for sincere affection substituting an eagerness to deceive and injure them in any way, are to be regarded as thefts. Though they may be obtained by an action at law, a different decision is given by God. He sees the long train of deception by which the man of craft begins to lay nets for his more simple neighbour, until he entangles himself in its meshes. (2.8.45)

The above quote well illustrates Calvin's position on market speculation and the rich oppressing the poor. It was directly influenced by what he observed in the Geneva of his time where wealthy traders exploited poor people, including migrant workers escaping from poverty to Geneva (Valeri 1997).

It is evident, then, that the reformed position on truthfulness and lying comprises a clear Christian-ethical and pastoral obligation to stay truthful and to avoid deceitful attitudes in all realms of life, including the realm of banking, financing and general commerce. There may be some small exceptions to this main rule, as when we are under professional obligations to keep secrets, for example in a counselling or advisory situation where we will be breaking our promise to keep the secrets entrusted to us which, in itself, will represent lying in the first place. However, such acceptance of concealment will not allow us to deceive others by way of utilising our especially entrusted knowledge earned under these unusual circumstances (Douma 1996).

\section{Greed}

When exploring the moral and pastoral obligations connected to banking, aspects of greed among the partakers and consideration of its morality and effects will be of interest.

Greed and problems connected with it are mentioned in numerous passages in Scripture. For example, in Psalm 10:3 we learn how 'the wicked man ... blesses the greedy and reviles the Lord', and in Proverbs 21:25-26 how 'the craving of a sluggard will be the death of him ... but the righteous give without sparing'. In the New Testament, for example in Hebrews 13:5 the instruction is, 'Keep your lives free from the love of money and be content with what you have', which is followed up by 1 Timothy 6:10, 'For the love of money is a root of all kinds of evil.' From Luke 12:15 we are urged to 'be on your guard against all kinds of greed; life does not consist in an abundance of possessions'. With regard to thirsting for money, Ecclesiastes 5:10 informs us that 'whoever loves money never has enough', and the consequences thereof are revealed in Matthew 6:24, 'No one can serve two masters. Either you will hate the one and love the other ... you cannot serve both God and money.' Clearly then, in both the Old and New Testament we find an abundance of sources explaining how greed for wealth in general, and for money in particular, will make us turn away from God and shun our societal task 
of caring for everyone and everything found in God's creation (Gn 2:15).

In his Harmony of the Law, when commenting on how the Israelites built the tabernacle as described in Exodus 36, Calvin (2017a) writes:

We know how few restrain themselves when an opportunity is given of thieving without detection; and, even if there be no disposition to deceive, yet most people are tempted by ambition, greedily to long for more to pass through their hands than they need. (p. 338)

Calvin's position on greed and gluttony as sinful has remained the main position within the reformed paradigm to this day. It has stood the test of time through vastly changing Western societies and will be of substantial guidance when establishing a prudent Christian-ethical and pastoral framework for banking and financing (Gushee \& Stassen 2016).

\section{Covetousness}

Greed and covetousness are frequently seen as near synonyms - there clearly are overlapping aspects of these two attitudes. However, as greed typically pertains to an individual wanting more or too much, for that matter, covetousness or desire could be seen as wanting what we do not already have. This may well be instilled in others - actively and openly or covertly and indirectly. In a modern-day commercial setting, covetousness may be promoted through marketing, advertising and influencing by social and other media (Douma 1996). In the context of banking and financing, to instil in others a desire to acquire material goods may be a powerful motivator to lead them into financial agreements which they may not benefit from or may outright be harmed by.

The natural scriptural starting point on covetousness may be Exodus 20:17 which forms part of the Decalogue and pertains directly to matters of desiring what we do not already have. This commandment has a wide scope, as it refers to 'anything that belongs to your neighbour', and it relates to coveting both material goods ('your neighbour's house, ox or donkey') and carnal desires ('your neighbour's wife'). As with greed, it appears that in the Old Testament era the Israelites lived in a state of agrarian non-monetised society and the focus of the commandment reflects this by the use of examples and imagery. This notwithstanding, the passage connects to all forms of desire and with its location in the Decalogue, it may be inferred that this instruction is on the highest level of importance (Thompson 1996). The central ethos of the commandment, in contrast to pure greed and gluttony, relates to the desire to possess what we do not have, rather than more of what we already possess.

In Harmony of the Evangelists, Calvin (2017b) comments on the wider scriptural position on greed and desire:

Men are grown mad with an insatiable desire of gain. Christ charges them with folly, in collecting wealth with great care, and then giving up their happiness to moths and to rust, or exposing it as a prey to thieves. What is more unreasonable than to place their property, where it may perish of itself, or be carried off by men? ... particularly, when God allows us a place in heaven for laying up a treasure, and kindly invites us to enjoy riches which never perish. (p. 291)

Again, the priority of the believer is clear. Calvin reminds us of the close connection between greed and desire where one may lead to the other and create a destructive evil circle for the individual and society (Pigott 1995:267). This theological position remains the reformed one and holds true today as ever before, but the pressures of destructive consumerism may instil a new form of covetousness in the general public for an ever-increasing spending and acquiring of material goods - something which may be spurred on by different modes of marketing and moneylending (Douma 1996).

\section{Harmful banking practices}

Emanating from scriptural interpretations in concert with a constructive Christian-ethical and pastoral approach, several modes of banking and financing, currently in practical use in the international market, will be deemed immoral under the reformed paradigm. In Bøsterud (2018), a comprehensive evaluation of such opportunities is performed and findings there demonstrate that such immoral banking practices typically will include:

- Banking practices that include lending to those in a state of urgent and desperate need.

- Banking practices that include borrowing without safeguarding sufficient means to pay back to the lender.

- Banking practices that include a lending duration beyond a reasonable time for paying back and when connected to a purchased asset, not within the expected time of value depreciation of a connected asset, or where the security puts the borrower at economic risk or risk of losing his home.

- Banking practices that include charging interest rates that exploit the need of the borrower in an exorbitant manner.

- Banking practices that include exaggerated risk-taking and attendant financial structuring that exports risk onto others and/or society.

- Banking practices that include hiding the truth of a transaction and/or contribute to misleading others who may be affected.

- Banking practices that include the promotion or utilisation of greed.

- Banking practices that include the promotion of covetousness.

The above list of immoral banking practices is not meant to be exhaustive. For the ethically and pastorally concerned banking professional, the assessment of practical banking and financing against scriptural sources will be an on-going process.

\section{Beneficial banking practices}

Even though Christian-ethical and pastoral norms may indicate that certain banking practices are to be rejected, 
central tenets of the PBP methodology involves that an uncritical compliance to such norms may not automatically promote the best possible banking practices to occur - neither from an individual nor a societal vantage point, as such general principles would merely inform investment practices by negation (Bøsterud \& Vorster 2017). The aim of PBP is to identify modes of banking practice that would aid the advancement of the individual and society whilst exercising stewardship based on Christian-ethical and pastoral principles (Heitink 1999; Vorster 2007).

In developing PBP, a holistic, inclusive, constructive and practical version of pastoral theology is espoused where the performance of good deeds in appropriate contexts and the development of a praxis of promoting the good to the benefit of all people is at the core (Oden 1983; Osmer 2008; Heitink 1999; Vorster 2007). The authors perceive this theological foundation to be well suited to elucidate and inform the development of Christian banking in a Christian-ethical and pastoral perspective under the reformed paradigm.

\section{Lending}

When operating in the core area of banking, which is the activity of lending money to those who need or want it $\mathrm{Mt}$ 5:42), the onus will be on the banking practitioner to perform such activities in a constructive and non-exploitative manner. This will entail that loans should be given to those who are in need, but only to the degree that they are not in a state of desperation where other more charitable alternatives for aiding the potential lender will be prudent. When the lender extends a loan, it will be necessary to match this with the capabilities of the borrower to repay the loan and to ensure that this will be possible in a manner that will be agreed so that the borrower will remain in a state of dignity throughout the loan duration.

When the need of the borrower attains the character of 'want' such as in a business transaction (Ex 22:25), the balance among the parties may be more even, and thus, the lender may rely more on the sole discretion of the borrower as to whether he may be able to repay. The lender also needs to exert a certain stewardship in the situation by displaying an attitude of pastoral leadership towards the borrower if the lender has more experience than the borrower (Tidball 1997; Vorster 2017a).

\section{Borrowing and deposits}

The obligation of the banking practitioner to act responsibly and to exert shepherding leadership and societal stewardship is even more salient when borrowing to finance a bank's operations, not least by taking deposits from the general public. Borrowing must be performed in a responsible manner. The banking professional must ensure that the bank has sufficient funds - both as long-term capital reserves as well as short-term liquidity to meet its obligations to its lenders.
When taking deposits, it also becomes clear that the banking practitioner needs to observe obligations of guidance to the less professional, to explain that money may be lost even in deposits, and to shepherd those who need to understand the ramifications of this. Prudent bankers, then, only take deposits and borrow when they are certain that their repayment obligation will be observed in full.

\section{Duration and security}

When entering into a loan agreement, it will be of importance that this contains a duration that is meaningful as compared to both the possible depreciation of connected financed assets and the financial horizon of the parties. If the duration becomes longer than the existence of a financed asset, or the remaining loan amount is higher than the value of a depreciating asset, the loan agreement will attain characteristics of rent or investment and then other types of terms should apply. Regarding taking security: it will be important that such security will not deprive the borrower of central needs satisfaction such as housing and food. Even if a lender has a legal right to take security to use, this may only be performed without inflicting the reduced needs satisfaction on the lender (Dt 24:6; Ex 22:26-27). It will also be of utmost importance that if a loan depends on the pledges of people other than the principal borrower, it will be performed with the maximum caution, and those involved need to be guided to understand that a third-party pledge only imposes obligations on the pledger without any adjacent benefits (Pr 22:26).

\section{Charging interest}

When extending credit in any form in a professional setting, the mainstay in the Western world is to charge interest as the means to pay for the credit and alleviate some of the perceived repayment risk on the part of the lender (Casu et al. 2015). As interest charging is considered acceptable under the reformed paradigm in principle, the question here will be where a line may be drawn for when charged interest becomes too high or exorbitant so that it falls outside the morally acceptable level. A good guide here may be the talionic principle ( $\mathrm{Lv}$ 24:19-20) where both parties should be giving and taking in equal measure. In other words, a concept of 'value-for-money' or equity needs to be applied when shepherding borrowers who will enter into credit. A prudent banking professional, then, will apply such a principle of evenness when guiding a potential borrower. $\mathrm{He}$ or she will also make certain that the borrower understands what the cost will be and how this translates against the benefit reaped from entering into a loan.

\section{Risk and stability}

When utilising banking technologies as a means of societal or individual economic advancement, a full appreciation of how this is connected to risk and societal stability will lead to the structuring of financial instruments and their application in a manner where the risk of destabilising the economic 
systems in which they are applied is at a minimum. This would entail the use of utmost care when originating derivatives and opaque financial structures, and necessitates that all involved parties fully understand the societal reach and financial magnitude of each instrument in use as well as only issuing such instruments in a volume the market can assimilate without irresponsible risk build-up. This will mean that collateralised debt obligations connected to mortgages, for example, should only be issued for the purpose of ensuring a stable supply of mortgage lending to potential house buyers (Gotham 2009).

In addition to the careful application of financial instruments, it is also important to be responsible when applying financial leverage in trading and investment operations in order to safeguard human enjoyment of material goods (Ec 5:19). This will be especially important when performing speculative market operations connected to trading in securities and other assets, as the prudent use of leverage may lead to optimisation of capital in the best interests of society and the individual (Mt 25:14-30; Lk 19:11-27). The opposite, however, may have financially devastating consequences for the societal economy and a wide group of stakeholders (Edwards 1999). The aim, then, will be to apply financial leverage with care and utilise stewardship principles with extra-party stakeholder interests at heart when applying financial leverage in trading and investment operations.

\section{Truthfulness}

Topics concerning truthfulness in relation to banking may involve all aspects of credit giving and receiving. Examples here may be to ensure that a borrower is aware of all terms of a loan agreement such as duration, fees, security, the real interest rate per year, et cetera. Some of these aspects may be connected to wider marketing activities such as advertising credit cards or consumer loans, but also to how the concrete interparty dialogue is handled in a professional business setting (Douma 1996). It will be necessary to note here that for the individual banking practitioner involved in such marketing and utilisation of banking products, solely to adhere to formal governmental regulations such as the US Truth in Lending Act, in itself will not suffice to align with scriptural norms (Downes \& Goodman 2014). Thus, all banking activity needs to be truthful and transparent, and banking practitioners need to apply the truth in all aspects of their practice at all times (Ex 20:16).

\section{Greed and covetousness}

For the assessment of what could be considered beneficial banking practices connected to greed and covetousness, these will here be treated in combination, as the overlapping of these two attitudes would render separate treatment superfluous. When banking practices are to be assessed in connection with greed and covetousness, the matter relates to the issue of leadership on the part of the banking professionals - both when communicating with less professional potential borrowers as well as among themselves. The sphere for applying Christian-ethical and pastoral leadership will be substantially connected to greed and desire within the financial industry. A shepherding activity would be to guide potential borrowers as to whether they need to obtain more material goods (Ex 20:17) by way of financing and, for the bankers, whether earning more money through extending more credit really is necessary (Lk 12:15). Further extension of such didactic guidance would entail the promotion of thrift and responsible consumption to potential customers and practitioners, and to ensure that all marketing and structuring of banking products follows such an understanding. We realise that, to some, such evangelising may seem somewhat misplaced in a professional setting. However, as thrift and responsible consumption is the opposite of greed and covetousness and, as financing such lifestyle choices may also be profitable, promoting such stewardship in a professional setting will create a real-life practically oriented ministry where Christian-ethical and pastoral norms founded in Scripture are at the core.

\section{Operationalisation of Pastoral Banking Practice}

We have elaborated above some main and general principles for PBP and certain areas of application. As with other utilisations of Christian-ethical and pastoral principles in practice, to operationalise them in a practical setting will include a customising to the specific practical realm in which they will be used. To ensure the practicability of PBP use by banking practitioners, PBP will have to be translated into the specific area where the practitioner will utilise them and will have to be expressed in a strategic and product-based manner. Our recommendation to practitioners who contemplate utilising PBP strategies in their practice is firstly, to outline the product groups and the individual products and market segments they are aimed at; and secondly, to apply the PBP principles onto each product and potential customer group in an easily understandable and practically useable manner. Finally, any PBP-based specific regulations used in practice should be revised at regular intervals to ensure their compliancy to the actual practice, as this evolves in the market situation wherein the practitioners reside.

\section{Conclusion}

The PBP methodology is a proactive and constructive approach to banking and financing that does not accept passive norm obedience and evading immorality as acceptable for guiding banking practice as viewed in a Christian-ethical and pastoral perspective. Pastoral Banking Practice informs a constructive and shepherding systematic pertaining to banking and financing where individual and societal concerns are heeded at the core of the professional practice. Furthered PBP research is an on-going activity for the authors and we thus invite more participants into this field, as the expected growth in global populations and economies would explain our time as one where substantial difference may be made. 


\section{Acknowledgements Competing interests}

The authors declare that they have no financial or personal relationship(s) which may have inappropriately influenced them in writing this article.

\section{Authors' contributions}

M.B. is the main author, who did most of the research and writing. J.M.V. contributed supervisory guidance and overall writing input.

\section{References}

Barth, K., 2009, Church dogmatics, ed. G.W. Bromiley \& T.F. Torrance (eds.), T\&T Clark, Edinburgh.

Berkhof, L., 1969 [1950], Principles of biblical interpretation, Cushing Malloy Inc., Ann Arbor, MI.

Bøsterud, M., 2016, 'Public ownership and morality: Proposed investment guidelines of the Norwegian Sovereign Wealth Fund: A Christian ethical perspective', PhD thesis, Faculty of Theology, North-West University, Potchefstroom.

Bøsterud, M., 2018, 'Financing, credit, moneylending and charging of interest. A Christian-ethical and pastoral perspective', PhD thesis, Faculty of Theology, North-West University, Potchefstroom.

Bøsterud, M. \& Vorster, J.M., 2017, 'Reoriented investment protocol: A Christianethical perspective on investments', In die Skriflig/In Luce Verbi 51(1), a2202. https://doi.org/10.4102/ids.v51i1.2202

Calvin, J., 1845, 'De Usuris Responsum: Calvin's letter on usury', in C. Elliott (ed.) Usury: A scriptural, ethical and economic view, viewed 15 August 2018, from http://www.readcentral.com/chapters/Calvin-Elliott/Usury-A-Scriptural-Ethicaland-Economic-View/012

Calvin, J., 2012, Institutes of the Christian religion, Hendrickson Publisher, Peabody, MA.

Calvin, J., 2017a, Harmony of the law: Christian classics ethereal library, vol. 3, Grand Rapids, MI, viewed 12 August 2018, from http://www.ccel.org/ccel/calvin/ calcom05.toc.html

Calvin, J., 2017b, Commentary on the harmony of the evangelists, Christian classics ethereal library, vol. 1, Grand Rapids, MI, viewed 18 August 2018, from http:// www.ccel.org/ccel/calvin/calcom31.pdf

Casu, B., Girardone, C. \& Molyneux, P., 2015, Introduction to banking, Pearson Education, London.

CFO, 2017, viewed 5 August 2018, from http://www.christianfinanceobservatory. org/en/

Chewning, R.C., 1995, 'Debt', in D.J. Atkinson, D.F. Field, A.F. Holmes \& O. O'Donovan (eds.), New dictionary of Christian ethics and pastoral theology, pp. 286, InterVarsity Press, Downers Grove, IL.

Collier, P., 2008, The bottom billion: Why the poorest countries are failing and what can be done about it, Oxford University Press, Oxford.

Cramp, A.B., 1995, 'Economic ethics', in D.J. Atkinson, D.F. Field, A.F. Holmes \& O. O'Donovan (eds.), New dictionary of Christian ethics and pastoral theology, pp. 332, InterVarsity Press, Downers Grove, IL.

Derrida, J., 1997, Of grammatology, corrected edn, John Hopkins University Press, Baltimore, MD.

Douma, J., 1996, The ten commandments, P\&R Publishing, Phillipsburg, NJ.

Downes, J. \& Goodman, J., 2014, Dictionary of finance and investment terms, Barron's Educational Series, Hauppauge, NY.

Easterly, W., 2002, 'How did heavily indebted poor countries become heavily indebted? Reviewing two decades of debt relief', World Development 30(10), 1677-1696. https://doi.org/10.1016/S0305-750X(02)00073-6

Edwards, F.R., 1999, 'Hedge funds and the collapse of long-term capital management', The Journal of Economic Perspectives 13(2), 189-210. https://doi.org/10.1257/ jep.13.2.189
EY, 2016, EY World Islamic banking competitiveness report, viewed 15 August 2018, from http://www.ey.com/Publication/vwLUAssets/ey-world-islamic-bankingcompetitiveness-report-2016/\$FILE/ey-world-islamic-banking-competitivenessreport-2016.pdf

Foucault, M., 2002, The archaeology of knowledge, Routledge Classics, Abingdon.

Galbraith, J.K., 2009, The great crash 1929, Penguin Books, London.

Gotham, K.F., 2009, 'Creating liquidity out of spatial fixity: The secondary circuit of capital and the subprime mortgage crisis', International Journal of Urban and Regional Research 33(2), 355-371. https://doi.org/10.1111/j.1468-2427. 2009.00874.x

Graeber, D., 2012. Debt: The first 5000 years, Melville House Publishing, Brooklyn, NY. Grudem, W., 2013, Systematic theology: An introduction to biblical doctrine, InterVarsity Press, Nottingham.

Gushee, D.P. \& Stassen, G.H., 2016, Kingdom ethics: Following Jesus in contemporary context, 2nd edn., Eerdmans, Grand Rapids, MI.

Heitink, G., 1999, Practical theology: History, theory, action domains: Manual for practical theology, Wm. B. Eerdmans, Grand Rapids, MI.

Horne, C.F. \& Johns, C.H.W., 2007, The code of Hammurabi, Forgotten Books, Charleston, SC.

Jamaldeen, F., 2012, Islamic finance for dummies, John Wiley \& Sons, Hoboken, NJ.

Kettell, B., 2011, Introduction to Islamic banking and finance, vol. 1, John Wiley \& Sons, Hoboken, NJ.

Keynes, J.M., 1915, 'The island of stone money', Economic Journal 25(98), 281-283. https://doi.org/10.2307/2222196

Martin, F., 2014, Money: The unauthorised biography, Random House, London.

McManus, J., 2011, 'Revisiting ethics in strategic management', Corporate Governance 11(2), 214-223. https://doi.org/10.1108/14720701111121074

Neal, L., 2015, A concise history of international finance: From Babylon to Bernanke, Cambridge University Press, Cambridge.

Oden, T.C., 1983, Pastoral theology: Essentials of ministry, HarperCollins, San Francisco, CA.

Osmer, R.R. 2008, Practical theology: An introduction, Eerdmans, Grand Rapids, IL.

Pava, M.L., 2008, 'Why corporations should not abandon social responsibility', Journal of Business Ethics 83(4), 805-812. https://doi.org/10.1007/s10551-008-9666-7

Pigott, G.J., 1995, 'Covetousness', in D.J. Atkinson, D.F. Field, A.F. Holmes \& O. O'Donovan (eds.), New dictionary of Christian ethics and pastoral theology pp. 267-268, InterVarsity Press Downers Grove, IL.

Star, S.L. \& Griesemer, J.R., 1989, 'Institutional ecology, translations and boundary objects: Amateurs and professionals in Berkeley's Museum of Vertebrate Objects: Amateurs and professionals in Berkeley's Museum of Vertebrate Zoology, 1907-1939', Social Studies
org/10.1177/030631289019003001

Thompson, J.G.S.S., 1996, 'Desire', in I.H. Marshall, A.R. Millard, J.I. Packer \& D.J. Wiseman (eds.), New Bible dictionary, 3rd edn., p. 272, InterVarsity Press, Nottingham.

Tidball, D., 1997, Skilful shepherds: Explorations in pastoral theology, Apollos, Nottingham.

Valeri, M., 1997, 'Religion, discipline, and the economy in Calvin's Geneva', The Sixteenth Century Journal 28(1), 123-142. https://doi.org/10.2307/2543226

VanDrunen, L.D., 2015, 'Debt, risk, and grace', Journal of Markets and Morality 18(1), 61-80.

Vorster, J.M., 2007, Christian attitude in the South African liberal democracy, Potchefstroom Theological Publications, Potchefstroom, South Africa.

Vorster, J.M., 2017a, Ethical perspectives on human rights, Potchefstroom Theological Publications, Potchefstroom, South Africa.

Vorster, J.M., 2017b, 'Hermeneutic and ethics: The quest for a "biblical ethic", in S.P. van der Walt \& N. Vorster (eds.), Reformed theology today: Practicaltheological, missiological and ethical perspectives, pp. 139-154, AOSIS, Cape Town.

Weber, M., 2012, The protestant ethic and the spirit of capitalism, Renaissance Classics, Provo, UT.

Westminster Confession, 2010, The Westminster confession of faith, and catechisms, in modern English, Evangelical Presbyterian Church, Livonia, viewed 20 July 2018 from http://www.faithchurchpines.org/uploads/2/6/6/3/26631450/westminster confession_of_faith.pdf

Zeller, M. \& Sharma, M., 2000, 'Many borrow, more save, and all insure: Implications for food and micro-finance policy', Food Policy 25(2), 143-167. https://doi. org/10.1016/S0306-9192(99)00065-2 